原著

癌患者に扣けるリンパ球サブセットおよび NK 細胞活性の検討

岐阜県 木澤病院外科

田辺博渡辺進

担癌患者の免疫能を評価する目的で97名の癌患者について末梢血リンパ球, リンパ球 サブセット，NK 細胞活性 (NK 活性)を測定し Stage, Performance Status (PS), 栄養状態とを比較検討し以下の結果を得た。

担癌患者の NK 活性は Stage IV で有意に低値を示した. NK 活性はPS の進行にとも ない低下する傾向にあり，PS3，4では有意に低值であった。また栄盖不良の担癌患者の NK 活性は有意に低值で西った。

リンパ球サブセットのうち，OKT3，OKT4はStage I, PS1で有意に高く，OKT8は 進行により上昇する傾向を示した。 OKT4/OKT8は Stage 別では有意差を示さなかった が，PSが進行する注ど低下する傾向にあった。

NK 活性は癌患者の状態を良く反映し, 特に栄養状態と相関することが示唆された. 栄 盖状態によりリンパ球サブセットの比率の変動は一定の傾向を示したが NK 活性忹ど の相関性はないと考党られた。

索引用語：担癌患者, 細胞性免度, リンハ球サブセット, NK 細胞活性

\section{はじめに}

近年, 免疫学の進歩にともない担癌患者では細胞性 免疫, 単球機能などの生体防御機構に異常をきたすこ とが明らかにされつつある12)。したがって担癌患者の 免疫能を把握することは治療内容を決定し，予後を推 察する上でも重要なことと思われる。しかしヒトの癌 は一般に抗原性が低いため特異的な免疫能を評価する ことはむずかしく，非特異的な免度能を評価し総合的 に判断されるのが現状である。

今回著者らは各種の担癌患者の免疫能を評価する目 的で末梢血でのリンバ球数, リンパ球サブセット，さ らに NK 細胞活性を測定しこれらの值と Stage, Performance Status，栄盖状態と比較することによりこ れらの免疫学的因子が癌患者の状態を把握し予後を知 る指標となりらるかを検討したので報告する。

$$
\text { 対象 }
$$

1986年 4 月から1988年の 9 月までの 2 年半に当院外 科にて経験した癌患者97名を対象とした。内訳は胃癌 51名, 大腸癌24名, 膵臓癌11名, 乳癌11名で平均年龄 $65.2 \pm 13.0$ 歳, 男女比66：31であった（表 1 ）。

検查項目わよひ評価方法

1989年 2 月 18 日受付 1989年 5 月 16 日採用

\section{表 1 対象症例}

昭和61年 4 月から, 昭和63年 8 月までに当院で経験し た癌患者のうち97名を対象とした。

\begin{tabular}{|c|c|c|c|c|}
\hline & 症例数 & 年 罯 & 平均年峆 & $\begin{array}{c}\text { 男女比 } \\
(s: f)\end{array}$ \\
\hline 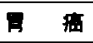 & 51 & $35 \sim 89$ & $65.4 \pm 13.0$ & $39: 12$ \\
\hline 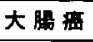 & 24 & $51 \sim 85$ & $69.5 \pm 9.9$ & $15: 6$ \\
\hline 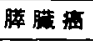 & 11 & $55 \sim 86$ & $70.6 \pm 7.9$ & 9: \\
\hline 乳 畐 & 11 & $34 \sim 73$ & $49.4 \pm 11.4$ & $0: 11$ \\
\hline 斯 & 97 & $34 \sim 89$ & $65.2 \pm 13.0$ & $66: 31$ \\
\hline
\end{tabular}

97名の癌患者についてそれぞれ胃癌取扱い規約3), 大腸癌取扱い規約(), 膵臓癌取扱い規的(5), 乳癌取扱い 規約苘にしたがい.Stage を決定し Stage I からIVまで に分類した（大腸癌の Stage V は Stage IV によくめ る).

癌患者の末梢血にてリンパ球数をるとめ，末梢リン パ球よりリンパ球サブセットとして OKT3, OKT4, OKT8，OKT4/OKT8，お゙よびNK細胞活性 (NK 活 性)をむとめた。

生化学検查より TP, ALBをもとめ, $\mathrm{TP}=6.5$, $\mathrm{ALB}=3.5$ 以上を栄盖良，それ未満を栄養不良とした。 さらにその際の Performance Status (PS) を表 $2 の$ 内容により評価した。 


\section{表 2 Performance Status}

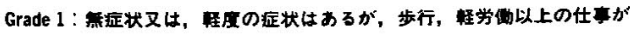
可能でる。

Grade 2 : 步行や身の回りのことはできる゙，時に少し介助がいることも ある。睡学何はできないが、日中の50\%以上は起居している。

Grade 3: 身の回りのカる程度のことはできるが、しばしば介助がいり， 日中の50\%以上は能床している。

Grade 4 ：身の回りのこともできずつなに介助がいり，䊏日就床を必要 としている。

\section{検查方法}

1. リンパ球サブセット

Tリンパ球サブセットの解析にはOrtho 社の溃光 標識モノクローナル抗体の, OKT3, OKT4, OKT8, を使用した，全血 $100 \mu l$ 至適濃度のモ/クローナル抗 体を $10 \mu l$ 添加， $4{ }^{\circ} \mathrm{C}, 30$ 分間インキュベートの後, 溶 血操作を加方遠心後 phosphate buffer saline (PBS) に再浮遊させて Flow cytometry (Spectrum III, Ortho 社）を用い細胞解析を行い全リンパ球に対する 陽性細胞をるとめた。 また同時採血の一般血液像にて 白血球 $(\mathrm{WBC})\left(/ \mathrm{mm}^{3}\right)$ リンパ球数 $(\mathrm{Lymph})\left(/ \mathrm{mm}^{3}\right)$ を求めた。

なお，OKT3は末梢血 Tリンパ球，OKT4はIn. ducer/Helper Tリンバ球, OKT8はSuppressor/ Cytotoxic Tリンパ球を標識するとされる.

\section{NK 活性}

末梢血リンパ球の NK 活性は以下の方法にて求め た。すなおち検査対象例の末梢血 $7 \sim 8 \mathrm{ml}$ をへパリン 加採血し, PBSにより 2 倍希䣋した後, FicollIropaque 比重遠心法にて単核球を分離し effector 細 胞とする。これに対し ${ }^{51} \mathrm{Cr}$ に標識したヒト慢性骨䯣性 白血病株 K562を Target とし，これらを一定の比率 $(1 / 20)$ にて混和し $37^{\circ} \mathrm{C} 5 \% \mathrm{CO}_{2} ， 4$ 時間培養後, 放出 された ${ }^{51} \mathrm{Cr}$ Auto well gamma system ARC30 (Aoka 製) にて測定し NK 細胞の K562細胞に対す る細胞障害性，すなわち\%lysisを次式により測定し NK 活性とした.

\section{NK 活性 $(\%)=$}

$\frac{\text { Experimental CPM-Control CPM }}{\text { Maximum CPM-Control CPM }} \times 100$

\section{評価方法}

末梢血リンパ球数、リンバ球サブセット，NK 活性を 免度学的指標とし、これらの検查結果を Stage, PS, 栄養状態と比較検討した。

また検定はStudents't-testにより $\mathrm{P}<0.05 て ゙$ 有意差
ありと判定した。

\section{結 果}

1. リンパ球サブセットと Stage, PS との関係

OKT3は Stage, PS ともに癌の進行の低い状態で高 い傾向を示し, Stage 別では Stage Iが他群に比して 有意に高値であり, PSではPS1が PS2, PS4に比して 有意に高値であった（図 1，2）.

OKT4 OKT3 と同様の傾向を示し, Stage I は他の Stage に比して有意に高値を示し，PS1は他群に比し て有意に高値を示した（図 3，4）.

OKT8と Stage の関係では, Stageの進行にともな

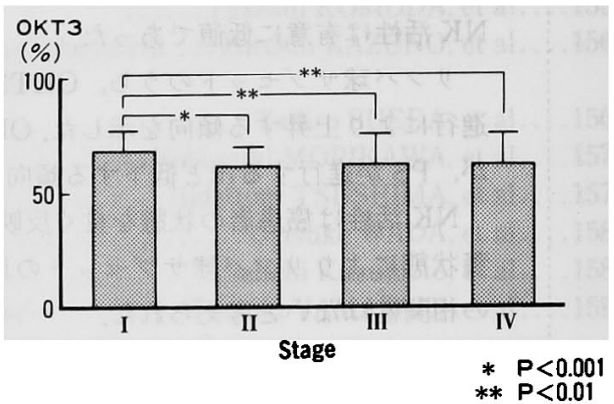

図 1 Stage と OKT3陽性細胞の割合

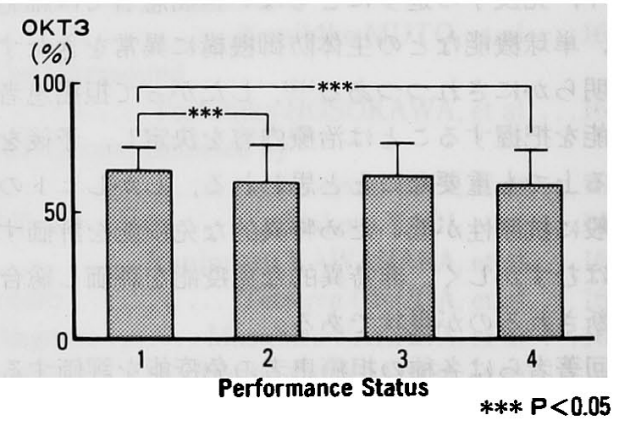

図 2 PS と OKT3陽性細胞の割合

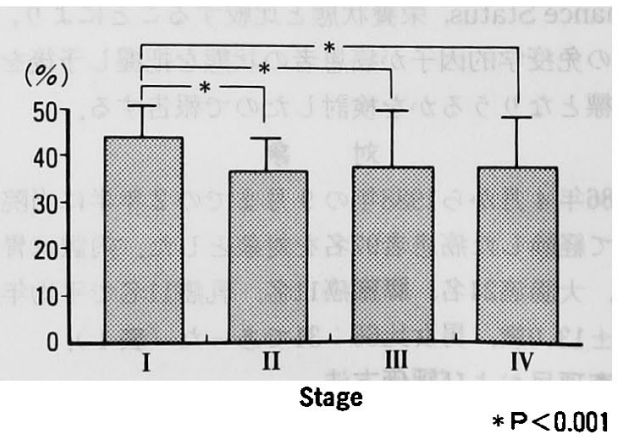

园 3 Stage と OKT4 


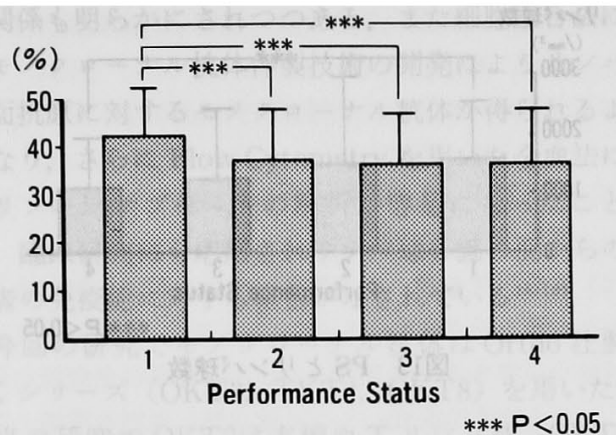

図 4 P.S.と OKT4

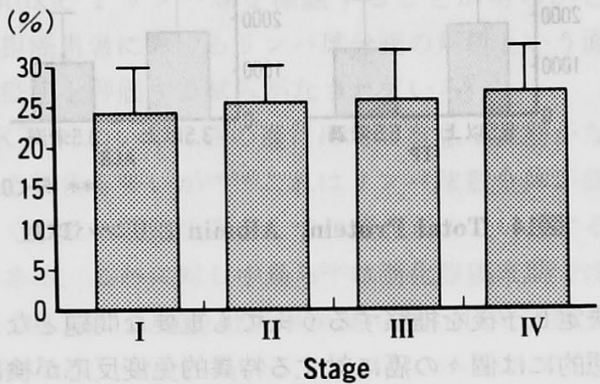

図 5 Stage と 0KT8

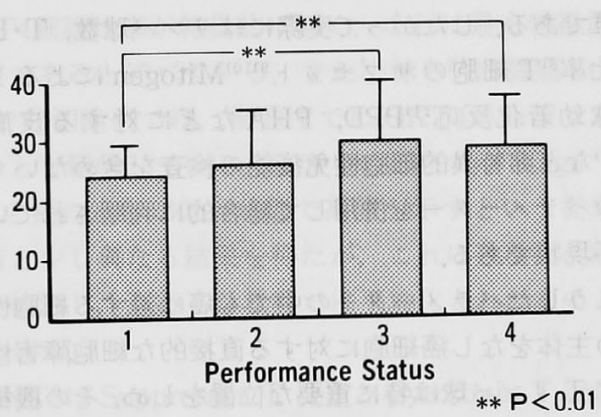

図 6 P.S.と OKT8

い上昇する傾向を認めたが有意差は認められなかっ た.PS との関係ではPSの進行にとるない上昇する傾 向を認め PS3，4 は PS1に比して有意に高値であった (図 5, 6).

OKT3/OKT4と Stage の関俰では, Stage の進行に よりやや低下する傾向があり Stage I とII，IVで有意 差を認めた。 PS との関係ではPSの進行にとるない低 下寸る傾向にあり PS3，4ではPS1に比して有意に低 值であった（図 7，8）。

2. NK 活性と Stage, PS, 栄菱状態との関係 NK 活性は，Stageの進行にとすない低下する傾向

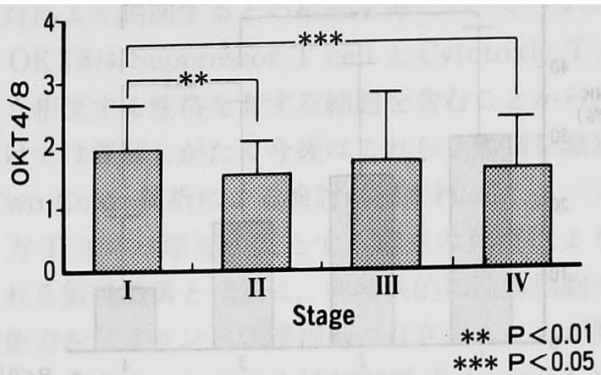

図 7 Stage と OKT4/8比

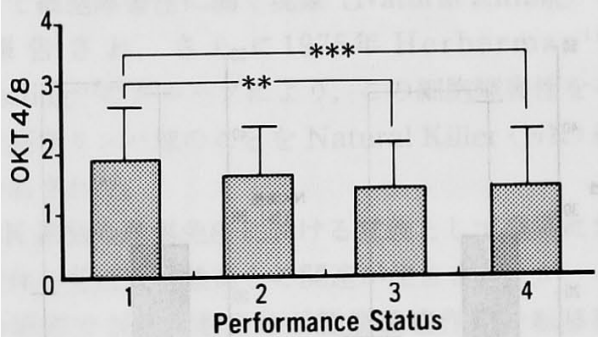

$* * \mathrm{P}<0.01$ $* * * \mathrm{P}<0.05$

図 8 PS と OKT4/8比

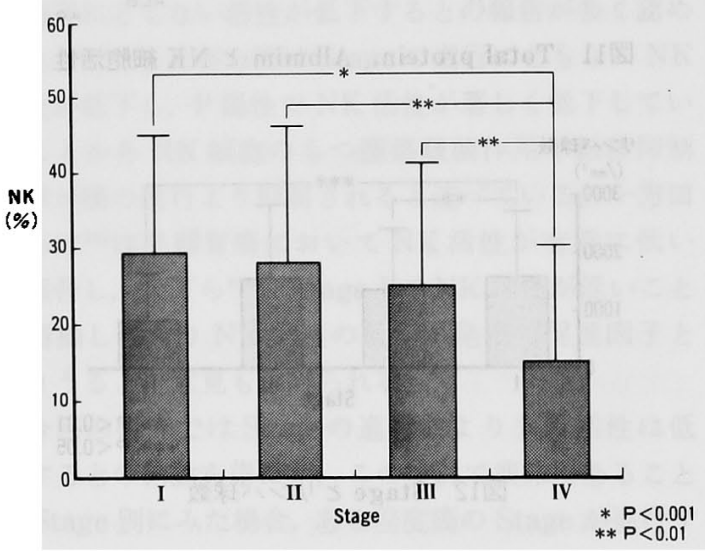

図 9 Stage と NK 細胞活性

を認め Stage IV で特に低く有意差を認めた（図９）. NK 活性ではPSの進行にともない低下を示し，PS4 では他群に比して有意に低值であり, PS3でも PS1, 2 に対し有意に低値であった(図10)，栄養状態と NK 活 性の関係では栄養不良ほど低值を示し，栄養良と不良 との間には有意差を認めた（図11）。

3.リンパ球数と Stage, PS, 栄荟状態との関係 リンパ球数は進行にともない减少する㑯向にあり Stage II, IV は Stage I に対し有意に低值であった(図 


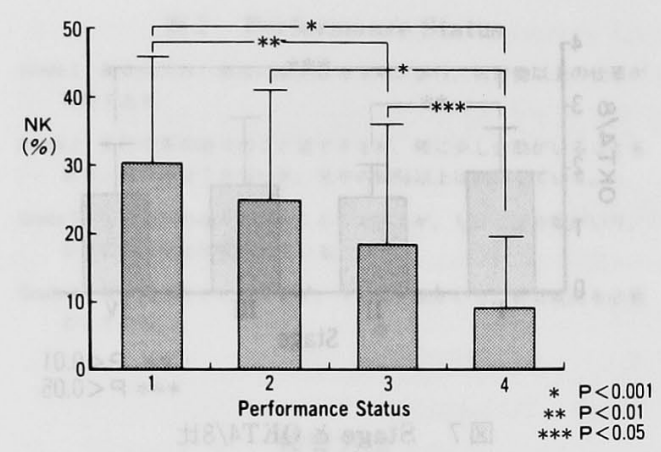

図10 PS と NK 細胞活性
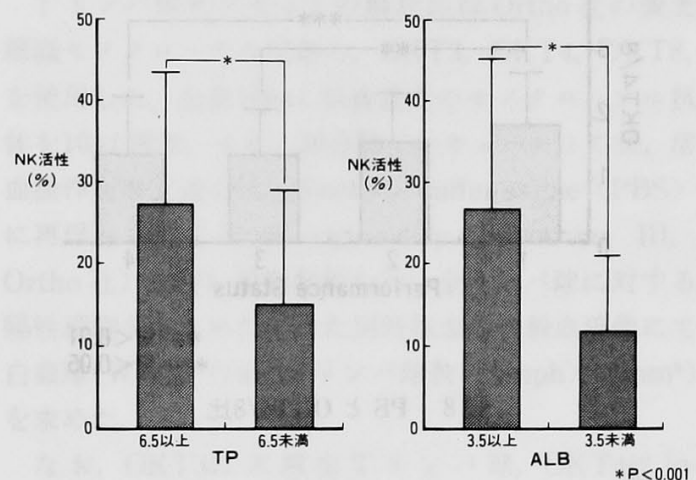

园11 Total protein, Albmim と NK 細胞活性

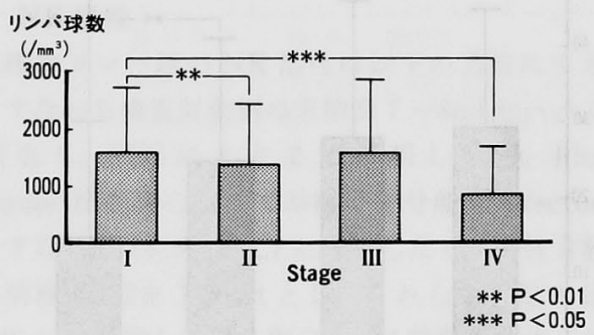

図12 Stage とリンパ球数

12).PS とリンパ球数とではPSの進行により,リンパ 球数は減少する傾向にありPS4ではPS1に比してり ンパ球数は有意に低值であった(図13)。リンパ球数は 栄養不良で低值を示す傾向にありALBでは有意差を 認めた（図14）。

\section{考察}

担癌生体においては免疫の調節機構に異常をきた し，これが癌の発生，転移，再発といった問題に大き く関与するすのと考学られている゙ことから癌患者の 免疫能の状態を正確に把握することは患者の治療方針

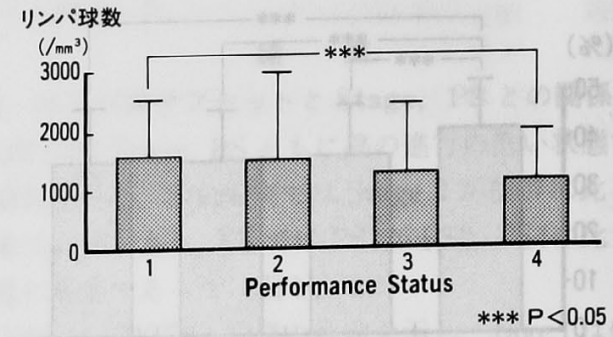

図13 PS とリンパ球数
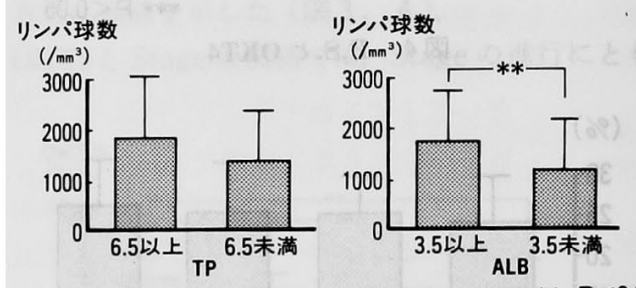

図14 Total Protein, Albmin とリンパ球数

を決定し予後を推察するらえです重要な問題となる。 理想的には個々の癌に対する特異的免疫反応が検出さ れることが必要であるが，現状では特異的な免疫反応 を一般化し,さらに臨床応用するということは非常に 困難である。したがって実際にはリンバ球数，T・B細 胞比率㝵T 細胞のサブセット ${ }^{910}$ Mitogenによるリン パ球幼若化反応 ${ }^{11} \mathrm{PPD}, \mathrm{PHA}$ などに対する皮虙反 応 ${ }^{21}$ など非特異的細胞性免疫能の検查を含めたいくつ かのパラメーターを併用して総合的に判断されている のが現状である。

こうしたパラメーターの中でも癌に対する細胞性免 疫の主体をなし癌細胞に対する直接的な細胞障害性を 示す Tリンパ球は特に重要な位置をしめ, その機構に ついて解明されつつある ${ }^{1314)}$.さらに, 最近ではこらし た Tリンハ球のような抗原認識にもとつく免疫性の 細胞障害機構とは無関保に, 腫瘍細胞障害活性を有す る Natural Killer (NK) 細胞が主体の腫煌監視機構の 中で重要な役割を担っていることが注目されてい $3^{15)-17)}$. T リン八゙球, NK 細胞に関する研究は, 近年 さかんになされるよらになっているが，これらのパラ メーターを同時に評価し得た報告は少なく, 今回の研 究でその意義について検討した。

細胞性免疫の主体をなすTリンパ球の癌細胞に対 する直接の細胞障害性については多くの報告がなされ ている ${ }^{14)}$. 最近の研究では Tリンバ球における個々の 分画の機能, 相互作用, 他の免疫能との関係など基礎 
的関係も明らかにされつつある。すた細胞融合法によ るモノクローナル抗体作製技術の開発によりリンパ球 表面抗原に対するモノクローナル抗体が得られるよう になり，さらに Flow Cytometry を用いた全血法によ るリンハ球サブセットの解析が容易になったことか ら，臨床研究にむ応用されリンパ球分画の面からの癌 患者の免疫能に対する報告がなされている18199.

今回の研究でモノクローナル抗体はOrtho 社製の OKシリーズ（OKT3，TKT4，OKT8）を用いたが， 従来の研究で OKT3は末梢血 Tリンパ球, OKT4は Inducer/Helper Tリンバ球, OKT8はSuppressor/ Cytotoxic Tリンパ球を標識することが明らかとさ れ，担癌患者におけるリンパ球分画の解析之いら面か ら免疫能を評価する試みがなされている。

OKT3については癌の進行に対し有意な变動がない とする報告も多いが(18)19)これはリンハ球数全体が低下 してくるため細胞比率としては変化が少ないとする考 えである。これに対し中島ら201は消化器癌末期では有 意に OKT3の低值の出現率が高く進行した状態での 指摽になりうるとしている。

OKT4については癌の進行により低下するとの意見 が多く ${ }^{18) 19921)}$ 佐藤ら ${ }^{18)}$ は良性疾患に比し胃癌患者では OKT4細胞比率が特異的に低く，これは最も特徵的な 所見であると述べている。また小林ら ${ }^{211}$ は胃癌 Stage IVで非切除例では, 術前すでに OKT4が低值であっ たことを報告している．著者らの研究では Stage I, PS1と癌の進行が低い状態で高値を示すといら従来の 報告と少し異なる結果を得たが，これは数種類の癌患 者を倹討し，進行した状態では平均化されたものと考 えられた。

OKT8は Suppressor $\mathrm{T}$ cell と Cytotoxic $\mathrm{T}$ cell $と$ いう相反するリンハ球をらくむが, 従来は Suppressor $\mathrm{T}$ cell の指標としての考之が強く，癌の進行にもとつ き Suppressor 細胞活性誘導性が上犁するために OKT8細胞比率は増加するとの報告が認められる9).

したがって OKT4/OKT8は癌の進行にすとづ， OKT4の低下, OKT 8增加がみられるとの理論からは 比較が低下することになり，実際そうした報告も多く みとめられる20122)。しかし比率は有意差がなかったと の報告も多く ${ }^{182) 23)}$ 単純に OKT4/OKT8の低下が免疫 能の低下を示すすのとしてょいのか疑問のむきすあ る。

今回の研究では OKT4/OKT8は癌の進行により低 下寸る傾向が認められ，さらに Stage の進行よりPS
の進行によく相関するとの結論を得たが，いずれにし ても OKT8は Suppressor T cell と Cytotoxic T cell という相反する性格を有する細胞を含むことから，こ れだけでは理解しがたく今後はこれら 2 種類を識別す る Two Color 解析による検討が望まれる。

一方 Tリンパ球を代表とする宿主の免疫により獲 得される監視機構とは別に, 非特異的に腫瘍細胞への 障害能力を示すリン八球様細胞の存在することが明ら かにされてきた。このことは1973年 Takasugi ら ${ }^{15)}$ より正常人の未感作リンパ球が種々の培養腫瘍細胞に 対して細胞障害性に働く現象（Natural Killing）とし て報告され，さらに1975年 Herberman ${ }^{16)}$ Kiessling ${ }^{17)}$ の゙ループにより，この細胞障害性を有す る末感作リンバ球のことを Natural Killer (NK) 細胞 と命名された。

NK 細胞の腫瘍免疫に抢ける意義として発癌に対す る主体の免疫監視機構との関連が注目されたが，その 後の研究で NK 細胞自体が腫湯破罗作用や転移抑制 効果を有することが in vivo で確認され担癌患者にお ける NK 細胞の役割が一層認識されている.

NK 活性と癌の進行度との関係については Stage の進行にともない活性が低下するとの報告が多く認め られる24) 26). 大谷ら ${ }^{26)}$ は Stage の進行にともない NK 活性が低下し，P陽性で NK 活性が著しく低下してい ることから NK 細胞のもつ腫滛破壊作用や転移抑制 作用が癌の進行より抑制されると述べている。一方田 中らは27》は早期胃癌に打いて NK 活性が有意に低い と報告し，大下ら ${ }^{28)}$ む Stage I でNK 活性が低いこと を指摘しており NK 活性の低下が発癌の促進因子と なりらるとの意見も認められる。

今回の研究では Stage の進行により NK 活性は低 下するとの結論を得たが，この検討で興味のあること は Stage 別にみた場合，ある程度癌の Stage が進行す ると急速に NK 活性が低下するのに対し，PS との比 較ではPS の進行により徐々にNK 活性が低下を示し たことである。このことから PSすなわち癌患者の一 般状態と NK 活性がより密接な関係にあるむのと考 えられた。

また担癌患者の免疫能に影響を与える要素の中で近 年栄養との関連を指摘する意見がある24).NK活性と 栄養についての報告は少ないが従来より栄養状態上生 体の感染防御能の関連については，興味をもたれてき た ${ }^{30)}$.さらに最近の免度学の進歩に伴い栄養の改善が 感染免疫のみならず，腫晹免疫や移植免疫においても 
重大な関連性を有することが指摘されてきてい $3^{3132)}$.

Akimoto ら ${ }^{33)}$ は，低蛋白食で飼育された $\mathrm{C} 3 \mathrm{H} / \mathrm{He}$ マウスのYAC-1細胞に対する Natural • Cytotoxity を調查し，正常飼育マウスでは OK-432や Lentinanな どの免疫賦活剤を投与してもNK 活性の増強は，みら れなかったとしている，また辻ら ${ }^{344}$ は，食道癌患者と NK 活性との関連について述へ，早期に低栄養状態と なる食道癌患者の NK 活性は他の消化器癌患者より 著しく低下していると報告し, 血清 ALB 值が $3.5 \mathrm{~g} / \mathrm{d} l$ 以下の低栄養状態では NK 活性の増強は期待できな いとしている.

今回の研究でも担癌患者の栄養状態と NK 活性は きわめてよく相関することが示されたが，このことは 栄盖のもつ腫愓免度への影響の大きさを示㖫するすの と考えられた。したがって Stage の進行した癌患者に 扣いてす栄養状態を改善させ，一般状態すなわち PS を向上させることが NK 活性を回復させ, 生体の免疫 能を賦活することになり，このことは今後の癌の治療 に执いてる大い期待しらるもの之考劣られた。

結 語

癌患者97名について，その末梢血リンパ球サブセッ ト，NK 活性を測定し Stage 栄養状熊との関係につい て検討し次の結果を得た。

1) OKT3, OKT4は Stage I, PS1 と癌の進行の低い 状態で高值を示した。

2）OKT8は癌の進行により低下する傾向にあり， OKT4/OKT8る同様であった。

3） NK 活性は Stage IV で低く，他の Stage に比し て有意に低値であった。

4）NK 活性と PSではPSの進行にともない有意 に低下を認めた。

5）NK 活性と栄養状態は良く相関し，栄養不良であ るはどNK 活性は低值を示した。

6) 末梢リンパ球数は Stage，PSの進行にとるない 低下する傾向を示した。

本論文の要旨は，第50回臨床外科学会総会にて報告した。 文献

1) Rokinson JC: Assays of immuno commpetence in the staging and prognosis of canser Surg. Gynecolobset 153 : 909-921, 1981

2) Unger SW, Bernhard ML, Pace RC, et al: Monocyte dysfunction in human cancer. Cancer $51: 669-674,1983$
3）胃癌研究会編：胃癌取扱い規約改訂第11版。金原 出版, 東京, 1985

4) 大腸癌研究会編：大腸癌取扱い規約改訂第 4 版, 金原出版，東京，1986

5）日本膵雹学会編：膵癌取扱い規約改訂第 3 版，金 原出版, 東京, 1986

6）乳癌研究会編：乳癌取扱い規約改訂第 8 版, 金原 出版, 東京, 1986

7）小川泰央：胃癌患者に拈ける非特異的免疫能に関 する臨床的研究ーリンパ球幼若化反応の評価之意 義一，日臨外医会誌 $45: 1016-1033,1984$

8) Yao $\mathrm{EH}, \mathrm{Li} \mathrm{D}, \mathrm{Cu} \mathrm{H}$ : T cell subpopulation in Hepatoma. Am J Gastroenteol 79: 227-228, 1984

9) Ginns LC, Miller LG, Goldenheim PD, et al: Alteration in immunore gulatory cells in Lung cancer and smoking. J Clin Immunol $2: 90-94$, 1982

10) Kaszubowski PA, Husby G, Tung KSK, et al : $T$-lymphocyte subpopulations in peripheral blood and tissues of cauce patients. Cancer Res $40: 4648-4657,1980$

11) Currie GA, Basham $C$ : Serum mediated inhibition of the patient to his own tumor: Apossible role for circlating antigen. $\mathrm{Br} \mathrm{J}$ Cancer 26 : 427-437, 1972

12）久野悟郎，兽根三郎，大口秀利他：皮席反応，癌の 臨 $24: 483-487,1978$

13) Wybran J, Hellstrom I, Hellstrom KE, et al: Cytotoxicity of human no sette-forming blood lymphocytes on cultivated human tumor cells. Int J Cancer $13: 515-521,1974$

14) Wybran J, Fudenberg $\mathrm{H}$ : Tlymusderived vosette-forming cells in various human disease states: Cancer, lymphom as, bacterial and viral infections and other disease. $J$ clin Invest 52 : 1026-1032, 1973

15) Takasugi M, Mickey MR, Terasaki PI: Reactivity of lymphocytes from normal person on cultured tumor cells. Cancer Res $33: 2898$ $-2902,1973$

16) Herberman RB, Hunn ME, Davin DH : Natural cytotoxic reactivity of mouse lymphoid cells against symgeneic and allogeneic tumors 1 . Distribution of reactivity and specificity. Int $\mathrm{J}$ Cancer 16:216-229, 1975 
17) Kiessling R, Klein E, Wigzell $\mathrm{H}$ : "Natural" killer cells in the mouse Moloney leukemia cells. Specificity and distribution according to genoty. pe Eur J Immuno 5: 112-117, 1975

18）佐藤元通，酒井 堅，青野幸治他：胃癌患者リンパ 球 subsets の検討, 日消外会誌 18：1645-1649, 1985

19）林 良夫, 佐藤光信, 古本奈奈代他：頭頸部癌患者 末梢りンパ球サブセットの異常一単クローン抗体 による解析，医のあゆみ $128: 507-508,1984$

20）中島芳道, 秋元 実, 岩崎秀康他：乳癌および消化 器末期患者の末梢血リンパ球分画の検討，癌の臨 32 : 1925-1928, 1986

21）小林一婎, 加藤 綮, 本田亮一他：胃癌手術前啳に おける非特異的免疫学的指標の推移，日消外会誌 $22: 43-52,1989$

22）横山三男, 大久保㢄二：モノクローナル抗体によ るリンパ球膜マーカーの検査とその臨床的意義, 日臨 43 (秋増) : 356-366, 1985

23）江里口直文, 内藤寿則, 友清 明他: 胃癌症例にお けるリンバ球 Subpopulationの分析, 日消外会誌 18 : $36-42,1985$

24) Pross HF, Baines MG: Spafaneous human lymphocyte-mediated cytoxicity against tumor forgets 1. The effect of malignant disease. Int J Cancer 8: 593-604, 1976

25) 前之原茂穗, 高尾尊身, 要甲 孝他: 消化器癌患者 に㧍ける Natural Killer (NK) 活性に関する臨床 的研究，日消外会誌 $18: 1824-1830,1985$
26）大谷吉明：胃癌患者に拈ける予後推定因子として の末梢血 Natural Killer 活性の検討, 日消外会誌 21 : 2535-2541, 1988

27）田中義憲, 青地 晨, 細川友秀他：胃癌患者におけ る Natural Killer 活性，医のあゆみ 111：438 $-441,1979$

28）大下裕夫, 佐治童豊, 杉山保幸他：胃癌症例におけ る術前 NK 活性の意義と術後 NK 活性低下に対 寸る非特異的免疫倵活剂術前 - 術後投与の効果に ついて, 日外会誌 $86: 1417-1425,1985$

29）小野寺時夫：進行消化器癌に対寸る抗癌療法と栄 羕指標, JJPEN 8:167-174, 1986

30) Law DK, Dudrick SJ. Abdou NI : The effects of protein calori malnutrition on immune competence of the surgical patient. Surg Gynecol Obstet $139: 257-266,1974$

31) McHugh MI, Wlkinson R, Elliott RW et al: Immunosuppression with polyunsaturated fatty acids in renal transplantation. Transplantation $24: 263-267,1977$

32) 西平哲朗, 秋元 実, 平山 克他 : 癌患者の栄堤と 免疫能, 輸液栄ジャ一ナル $2: 257-263,1980$

33）秋元 実, 西平哲朗, 葛西森夫他：低蛋白栄養下に おけるマウス免疫能の検討，臨免疫 13：396 $-402,1981$

34) 过 和男, 阿保七三郎, 工藤 保他：食道癌患者に 打ける Natural Killer 活性值の臨床的意義，日消 外会誌 $18: 8-14,1985$

\title{
STUDIES ON LYMPHOCYTE SUBSETS AND NATURAL KILLER CELL ACTIVITY OF THE PATIENTS WITH CANCER
}

\author{
Hiroshi TANABE and Susumu WATANABE \\ Department of Surgery, Kizawa Hospital
}

To evaluate the immune reactivity of the patients with cancer, peripheral lymphocytes, lymphcyte subsets, and natural killer cell activity (NK activity) were determined in 97 cancer patients, and their stages, performance status (PS), and nutritional status were comparativery studied.

A significant low level of NK activity was noted in stage IV patients, NK activity was decreased with advanced PS. It was significantly low at PS 3 and 4. A good coorelation between nutritional status and NK activity was observed, and a significantly decreased NK activity was noted in oligotrophia.

Among lymphcyte subsets, OKT 3 and 4 were significantly higher in stage i and PS1, and OKT8 appeared to increase with more advanced stage and PS. The OKT 4/OKT8 did not show significant difference depending on stages, however, tended to decrease with advanced PS.

It was suggested that $\mathrm{NK}$ activity reflects the condition of a cancer patient. Especially the good coorelation with nutrition was impressive. Though a certain tendency has been noted in the ratio of lymphcyte subsets, it appears to lack as good a coorelation as that in NK activity. 